Bidias-Menik, H.P., \& Tonmo, S.G. (2020). Interest rate predictability in some selected African countries. Copernican Journal of Finance \& Accounting, 9(3), 45-60. http://dx.doi.org/10.12775/ CJFA.2020.011

\author{
Hans Patrick Bidias-Menik* \\ University of Dschang-Cameroon \\ Simplice GaËl Tonmo** \\ University of Dschang-Cameroon
}

\title{
INTEREST RATE PREDICTABILITY \\ IN SOME SELECTED AFRICAN COUNTRIES
}

Keywords: interest rates predictability, expectation hypothesis, term structure of interest rates, African markets.

J E L Classification: E43, G17.

Abstract: This study tries to verify the predictive power of the implicit forward rate of the term structure of interest rates in Africa. We used data from Egypt, Ghana, Kenya, Nigeria and the Republic of South Africa. A modified version of the yield term premium and the forward term premium models of Shiller and McCulloch (1990) were used to test the predictive power of the implicit forward rate, rather than the rational expectations hypothesis. We both used FMOLS and DOLS estimators, since they are more consistent than OLS with non-stationary series. The overall results show that the implicit

Date of submission: September 11, 2020; date of acceptance: October 4, 2020.

* Contact information: hanspatrickbidias@gmail.com, Department of Accounting and Finance, Faculty of Economics and Management Sciences, University of Dschang, Ouest Region, Cameroon, phone:+237679261349; ORCID ID: https://orcid.org/00000002-4655-5787.

** Contact information: gaeltonmo@gmail.com, Department of Accounting and Finance, Faculty of Economics and Management Sciences, University of Dschang, Ouest Region, Cameroon, phone:+237696881738; ORCID ID: https://orcid.org/0000-00022818-5575. 
forward rate does not have a significant predictive power in Africa. It therefore appears that operators on African markets should not rely on those predictions.

\section{IIINTRODUCTION}

The predictability of interest rates is a financial problem that preoccupies several categories of economic agents. Indeed, in order to avoid capital losses or to expect huge gains, a lender on capital market has to get an idea of what will be the future level of interest rates. Similarly, in order to minimise the capital cost, a borrower needs to know what will be the future level of interest rates.

Some old neoclassical school authors including Fisher (1896), Lutz (1940) and Meiselman (1962), thought that the future level of interest rates can be predicted through the term structure of interest rates (or yield curve). It represents the relationship between bond yields that are theoretically considered to be risk-free, and their maturities at a given date (Mishkin, 2010). The future level of interest rate is then known, given the implicit forward rate in the term structure of interest rates.

These authors were criticised by others from the monetarist school including Hicks (1939) and Modigliani and Sutch (1966) on the fact that operators on the market are not gods alike to know with certainty what will be in the future. Taking into consideration the risk, they proposed to add a premium (liquidity premium or risk premium) to the term structure of interest rates. In those conditions, the future level of interest rate would be the implicit forward rate plus the liquidity or risk premium. Considering the fact that operators should have rational expectation on the market, Roll (1968) and Sargent (1972) proposed a model where the forward rate is the expected rational interest rate, which gave what is called in the financial literature the expectation hypothesis. But what credit should be given to the predictions of the implicit forward rate of the term structure of interest rates in Africa?

This study tries to verify the predictive power of the implicit forward rate of the term structure of interest rates in Africa. That is to test the empirical validity of the expectations hypothesis in Africa. The model of Shiller and McCulloch (1990) was used to this end. But, rather to use a rational expected short rate as it is common in the literature, following Guidolin and Thornton (2008) and Bulkley, Harris and Nawosah (2013), we used the implicit forward rate as the short rate predicted. We used data from Egypt, Ghana, Kenya, Nigeria and the Republic of South Africa. 
The rest of the paper is organized as follows: after this introductive section, the next section presents a literature review on interest rate predictability through the term structure of interest rates. The third section presents the research methodology and the course of the research process, the fourth presents the results and discussions, and the sixth section presents the conclusion.

\section{LITERATURE REVIEW}

\section{Theoretical framework of interest rate predictability through the term structure of interest rates}

The term structure of interest rate was first describes by Fisher (1896), who proposed a mathematical equality between the yield of a long term security and the total yield of short term securities, along the long term maturity. But his theory was formalised by Lutz (1940) in his expectations theory. Lutz (1940) described operators in the capital market as insatiable and motivated by a single goal: profit maximisation. In this context, they would try to take advantages of any arbitrage opportunities offered by a market in a situation of disequilibrium, that is a market where:

$$
\left(1+R_{t}^{(n)}\right)^{n} \neq\left(1+r_{t}^{(1)}\right)\left(1+r_{t+1}^{(1)}\right) \ldots\left(1+r_{t+n}^{(n)}\right)
$$

Where $\mathrm{R}_{\mathrm{t}}^{(\mathrm{n})}$ is the long term rate of maturity $\mathrm{n}$, and $\mathrm{r}_{\mathrm{t}}^{(1)}$ is the current short rate, and $\mathrm{r}_{\mathrm{t}+\mathrm{i}}^{(1)}$ is the future rate at time $t+1, t+2, t+3, \ldots, t+n$.

Lutz (1940) suggested that, while they are trying to take advantage of this disequilibrium situation, operators on the capital market will contribute to bring the market back in a situation of general equilibrium. The general equilibrium equation is as follows:

$$
\left(1+R_{t}^{(n)}\right)^{n}=\left(1+r_{t}^{(1)}\right)\left(1+r_{t+1}^{(1)}\right) \ldots\left(1+r_{t+n}^{(n)}\right)
$$

The future short rates in that equilibrium context are called the implicit forward rates. Considering the fact that at $\lim _{x \rightarrow 0} \ln (1+\mathrm{x})=x$, Sargent (1972) rewrite it as follows: 


$$
\mathrm{R}_{\mathrm{t}}^{(\mathrm{n})}=\frac{1}{\mathrm{n}} \sum_{i=0}^{n-1} \mathrm{r}_{\mathrm{t}+\mathrm{i}}^{(1)}
$$

This is to say that the long-term yield is a portfolio of short term yield of the same maturity and equivalent weight. Lutz (1940) was criticised on the fact that he assumed that operators are gods alike, knowing with certainty all the future short interest rates. Since this is not true, there is a risk that should be priced. Hick (1939) calls it a liquidity premium in his liquidity premium theory, while Modigliani and Sutch (1966) call it the risk premium in his preferred habitat theory. The general equilibrium becomes in this context as follows:

$$
\mathrm{R}_{\mathrm{t}}^{(\mathrm{n})}=\frac{1}{\mathrm{n}} \sum_{i=0}^{n-1} \mathrm{r}_{\mathrm{t}+\mathrm{i}}^{(1)}+\pi_{i}
$$

Where represents the risk premium or the liquidity premium corresponding to the ith expected rate, with $\pi_{0}=0$. The expectations hypothesis, as it is defined in the literature, considers all these three theories.

\section{The tests of expectation hypothesis in the literature}

There are several approaches to test the expectation hypothesis in the financial literature, including the standard models of Shiller and McCulloch (1990), the VAR models of Campbell and Shiller (1991) and the orthogonal models of Bekaert, Hodrick and Marshall (1997). The standard models of Shiller and McCulloch (1990) and the orthogonal models of Bekaert et al. (1997) are determined from the ex-post risk premium. Indeed, three time-independent term risk premiums can be distinguished: the yield term premium, the forward term premium and the holding-period premium (Shiller \& McCulloch, 1990). But, while the orthogonal models consider the ex-post term premium as an unpredictable "surprise" under the expectation hypothesis (the regression coefficient of the long or short rate on that premium should be null), the standard models of Shiller and McCulloch (1990) are simple linear regression models where the dependent variable is a rate variation and the explanatory variable a spread (Jondeau \& Ricart, 1999). 
The orthogonal models seek to resolve the problem of the poor small samples properties of the standard model (Longstaff, 2000). They used a Monte Carlo simulation to this end. But they are unclear about the predictive power of the implicit forward rate. The VAR model of Campbell and Shiller (1991) also try to deal with the standard models biases, including overlapping errors. This approach provides some information about the similarity of current spread movements relatively to those implied by the expectations hypothesis (Campbell \& Shiller, 1991). If the purpose is to evaluate the ability of the expectation hypothesis to predict the slope of the yield curve, then the linear regression would not be the most appropriate method (Campbell \& Shiller, 1991). But if one's purpose is merely to test the theoretical model of expectation hypothesis, then the regression method using the standard model would be simpler (Campbell \& Shiller, 1991). Since this is the case in this study, we use the standard model of Shiller and McCulloch (1990).

Several studies have been made, in the literature, using standard tests, including Fama (1984), Mankiw and Miron (1986), Fama and Bliss (1987), Froot (1987), Shiller and McCulloch (1990), Campbell and Shiller (1991), Hardouvelis (1994), Bulkley et al. (2013), on American data's; Jondeau and Ricart (1999) and Guidolin and Thornton (2008) on Euro-devises data's, Gerlach (2003) on Hong Kong interbank market data's, and among the most recent, Boamah (2016) on Ghanian data's, and Bidias and Kamdem (2017) on West African Economic and Monetary Union (WAEMU) interbank market data's. All these studies but the one of Jondeau and Ricart (1999) rejected the expectation hypothesis on each market in question.

It is important to note that all these studies but those of Guidolin and Thornton (2008) and Bulkley et al. (2013) used the rational expected short rate as the predicted future short rate. If the need to consider that operators on the market are rational is understandable, this does not provide clear information's about the predictive power of the implicit forward rate. So rather to use it as it was defined by Shiller and McCulloch (1990), following Guidolin and Thornton (2008) and Bulkley et al. (2013), we consider the implicit forward rate as the predicted rate. The details are given in section 3 bellow. 


\section{THE RESEARCH METHODOLOGY AND THE COURSE OF THE RESEARCH PROCESS}

\section{The data}

In this study, we used data of several African countries, including the Republic of South Africa, Nigeria, Egypt, Ghana, and Kenya. This choice is based on the fact that their stock exchange markets are among the most successful in Africa, in terms of market capitalisation. Stock returns on financial markets are indeed evaluated with reference to the term structure of interest rate on money market, since securities on this market are theoretically considered free from default risk.

While interbank market rates were used for the Republic of South Africa and Nigeria, treasury bills rates were used for Egypt, Kenya and Ghana. The choice of one or the other in this study depends solely on data's availability. The data used have been collected on the website of each central Bank concerned. We used monthly rates of three months, six months and twelve months over the period from January 2010 to May 2017. This is a period after the international financial crisis of 2007-2008, the idea here being to minimise the effects of this crisis on agents expectations.

Since it is assumed in the literature and in practice that there is a relationship between short terms rates on the market, the maturities considered are less than one year. The choice of those used is based on the fact that they are the most used rates in empirical studies. In addition, three-month and six-month rates represent the most commonly used reference rates on interbank markets. They were therefore considered as short-term rates in this study - that is the rates that are anticipated by agents.

Data of Ghana and Nigeria were directly obtained with a monthly frequency, while those of the Republic of South Africa, Egypt and Kenya were obtained initially with a weekly frequency. They were therefore grouped monthly from a simple arithmetic mean. The time series obtained had some missing observations. For Ghana, there was one missing observation about 3-month rate of T-bill. For Kenya, there was one missing observation about the 3-month rate series, one missing observation for the 6-month rate series, and 6 missing observations for the 12-month rate series. The missing observations not exceeding one period for each of these series, we filled the gaps with a simple linear interpolation. 
For Egypt, there was a total absence of transactions between January and October 2015 for the 3-month rate series, and between January and December 2015 for the 6-month and 12-month rate series (a whole year). Last Observations Carry Forward (LOCF) and Next Observation Carry Backward (NOCB) techniques were used for $50 \%$ of consecutive voids.

\section{Methods of data analysis}

We mentioned supra that Shiller and McCulloch (1990) distinguishes three term risk premiums: the yield term premium, the forward term premium and the holding-period premium. He derived three models from these term premium as follows:

$$
\begin{aligned}
& \frac{1}{k} \sum_{s=0}^{k-1}\left(E_{t} r_{t+s m}^{(m)}-r_{t}^{(m)}\right)=\alpha+\beta\left(R_{t}^{(n)}-r_{t}^{(m)}\right)+\varepsilon_{t+n}, \quad \text { with } 0<m<n \\
& E_{t} r_{t+k}^{(m)}-r_{t}^{(m)}=\alpha+\beta\left(f_{t}(k, k+m)-r_{t}^{(m)}\right)+\varepsilon_{t+k+m} \\
& E_{t} R_{t+m}^{(n-m)}-R_{t}^{(n)}=\alpha+\beta \frac{m}{n-m}\left(R_{t}^{(n)}-r_{t}^{(m)}\right)+\varepsilon_{t+n}
\end{aligned}
$$

Where $E_{t} r_{t+s m}^{(m)}, E_{t} r_{t+k}^{(m)}$, and $E_{t} R_{t+m}^{(n-m)}$ are the rational expected rates, $f_{t}(k, k+m)$ is the implicit forward rate in the current term structure, $R_{t}^{(n)}$ and $r_{t}^{(m)}$ are respectively the current long term (n period) and short term (m period) rate, with $\mathrm{k}=\mathrm{n} / \mathrm{m}, \varepsilon$ is a with noise.

In this study, we only used the models (5) and (6), for the model (7) assumes that $\mathrm{k}>2$. Since we are not testing the rational expectations hypothesis, those models were reformulated to test the predictive power of the implicit forward rate as follows:

$$
\frac{1}{k} \sum_{s=0}^{k-1}\left(r_{t+s m}^{(m)}-r_{t}^{(m)}\right)=\propto+\beta\left(R_{t}^{(n)}-r_{t}^{(m)}\right)+\varepsilon_{t+n} \text {, with } 0<m<n
$$




$$
r_{t+k}^{(m)}-r_{t}^{(m)}=\alpha+\beta\left(f_{t}(k, k+m)-r_{t}^{(m)}\right)+\varepsilon_{t+k+m}
$$

Where $r_{t+s m}^{(m)}$ and $r_{t+k}^{(m)}$ are the forward rates respectively at time $\mathrm{t}+\mathrm{sm}$ and $\mathrm{t}+\mathrm{k}$. considering the fact that $\mathrm{n}=2$ and $\mathrm{m}=1$ in this study, the models can be rewrite as follows:

$$
\begin{aligned}
& \frac{1}{2}\left(r_{t+1}^{(1)}-r_{t}^{(1)}\right)=\alpha+\beta\left(R_{t}^{(2)}-r_{t}^{(1)}\right)+\varepsilon_{t+n} \\
& r_{t+1}^{(1)}-r_{t}^{(1)}=\alpha+\beta\left(f_{t}(1,2)-r_{t}^{(1)}\right)+\varepsilon_{t+k+m}
\end{aligned}
$$

In each equation, $\beta$ capture the predictive power of the implicit forward rate in the current term structure. Indeed, in (3.6), the spread $\left(R_{t}^{(2)}-r_{t}^{(1)}\right)$ is supposed to be mathematically equal to the half rate variation predicted by the implicit forward rate. It is therefore regress on the realized variation in order to know the predictive power of the implicit forward rate. The regression coefficient $\beta$ will be equal to 1 if the implicit forward rate is a perfect foresight indicator of short terms interest rates movements.

Since (10) and (11) are simple linear regression models, all the preliminary tests of stationarity, co-integration, normality, autocorrelation of errors and heteroscedasticity were done to ensure the relevance of the results. Indeed, it is well known in the literature that financial series are often non-stationary. In fact, all the interest rates series were prove to be I(1) by the Dikey Fuller Generalize Least Square.

In that context, estimations made using OLS will be inconsistent, for the fact that inferences using the normal tables will not be valid - even asymptotically (Arize, Malindretos \& Ghosh, 2015). OLS estimates will be biased in that context, while FMOLS of Philips and Hansen (1990) and DOLS of Stock and Watson (1993) will not (Arize et al., 2015). Both DOLS and FMOLS are usually preferred to the OLS since they take care of small sample and endogeneity bias (Montalvo, 1995).

DOLS is a parametric approach which seeks to address asymptotic bias contained in the OLS estimates by including leads and lags of the first difference of the independent variables. Lags and leads are introduced to deal with the problem of the order of integration and the existence or absence of cointegra- 
tion (Anastasiou, Louri \& Tsionas, 2016). Furthermore, white heteroskedastic standard errors are used.

Nevertheless, the parametric DOLS is preferred to the non-parametric FMOLS, for the FMOL (unlike the DOLS) imposes additional requirements that all variables should be integrated of the same order [i.e.,I(1)] and that the regressors themselves should not be cointegrated (Masih \& Masih, 1996). In addition, according to Kao and Chiang (2000) DOLS estimator is the best estimator overall. They asserted that DOLS outperforms both OLS and FMOLS. For these authors, the DOLS differs from the FMOLS estimators in that the DOLS requires no initial estimation and no non-parametric correction. Not only it's computationally simpler, but it reduces bias better than FMOLS. The t statistic from DOLS converges to the standard normal density much better than the statistic from FMOLS. In order to guarantee the robustness of the result, we both used FMOLS and DOLS in this study.

\section{RESULTS AND DISCUSSIONS}

It appears from analysis results that the implicit forward rate does not have a significant predictive power in Egypt, Ghana and Kenya. The results are the same, irrespective of the model or the estimation method used. Thus, operators in those countries should not rely on the predictions of the implicit forward rate of the term structure of interest rates to get an idea of what would interest rates be in the future. Those results are partially consistent with Boamah (2016) in Ghana, since he found a significant but low predictive power of the implicit forward rate. The results are also consistent with Guidolin and Thornton (2008) on Euro-devises, and those of Bulkley et al. (2013) and Bulkley, Harris and Nawosah (2015), even though they also found a partial but low predictive power of the implicit forward rate. The later explain that failure by two behavioural biases: the law of small number and conservatism. 
Table 1. Results of the FMOLS estimations

\begin{tabular}{|c|c|c|}
\hline & $\beta\left(\sigma_{\theta}\right)$ & $R^{2}$ \\
\hline \multicolumn{3}{|l|}{ EGYPTH } \\
\hline \multicolumn{3}{|l|}{ Model (3.6) } \\
\hline (3months; 6months) & $0.3611(0.1723)$ & 0.1384 \\
\hline (6months ; 12 months) & $0.8420(0.4404)$ & -0.1108 \\
\hline \multicolumn{3}{|l|}{ Model (3.7) } \\
\hline (3months ; 6months) & $0.3517(0.1669)$ & 0.1411 \\
\hline (6months ; 12 months) & $0.8241(0.4297)$ & -0.1120 \\
\hline \multicolumn{3}{|l|}{ GHANA } \\
\hline \multicolumn{3}{|l|}{ Model (3.6) } \\
\hline (3months ; 6months) & $-0.2767(0.2145)$ & -0.0050 \\
\hline (6months ; 12 months) & $0.0412(0.1846)$ & 0.0080 \\
\hline \multicolumn{3}{|l|}{ Model (3.7) } \\
\hline (3months ; 6months) & $-0.2645(0.2116)$ & -0.0045 \\
\hline (6months ; 12 months) & $0.0646(0.2024)$ & 0.0121 \\
\hline \multicolumn{3}{|l|}{ KENYA } \\
\hline \multicolumn{3}{|l|}{ Model (3.6) } \\
\hline (3months; 6months) & $0.0613(0.0924)$ & 0.0142 \\
\hline (6months ; 12 months) & $0.1872(0.1285)$ & -0.0388 \\
\hline \multicolumn{3}{|l|}{ Model (3.7) } \\
\hline (3months ; 6months) & $0.0578(0.0842)$ & 0.0144 \\
\hline (6months; 12 months) & $0.1759(0.1101)$ & -0.0418 \\
\hline \multicolumn{3}{|l|}{ NIGERIA } \\
\hline \multicolumn{3}{|l|}{ Model (3.6) } \\
\hline (3months ; 6months) & $-0.0707(0.0673)$ & 0.0407 \\
\hline (6months; 12 months) & $-0.1460(0.0467)^{* *}$ & 0.0599 \\
\hline \multicolumn{3}{|l|}{ Model (3.7) } \\
\hline (3months ; 6months) & $-0.0731(0.0684)$ & 0.0438 \\
\hline (6months ; 12 months) & $-0.1648(0.0439)^{* *}$ & 0.0602 \\
\hline \multicolumn{3}{|l|}{ SOUTH AFRICA } \\
\hline \multicolumn{3}{|l|}{ *Model (3.6) } \\
\hline (3months ; 6months) & $0.0703(0.0334)^{* *}$ & 0.0670 \\
\hline (6months ; 12 months) & $0.1078(0.1081)$ & -0.0146 \\
\hline \multicolumn{3}{|l|}{ Model (3.7) } \\
\hline (3months; 6months) & $0.0691(0.0253)^{* *}$ & 0.0781 \\
\hline (6months ; 12 months) & $0.1062(0.1050)$ & -0.0153 \\
\hline
\end{tabular}

$\mathrm{N}$ o t e : Mean (standard deviation) of the regressor coefficient in the second column and determination coefficient in the third column. ${ }^{*}{ }^{* *}$ denote significance at $10 \%$ and $5 \%$ respectively.

S o u r c e : authors' computation from Stata 10/1 outputs. 
Table 2. Results of the DOLS estimations

\begin{tabular}{|c|c|c|}
\hline & $\beta\left(\sigma_{\theta}\right)$ & $R^{2}$ \\
\hline \multicolumn{3}{|l|}{ EGYPTH } \\
\hline \multicolumn{3}{|l|}{ Model (3.6) } \\
\hline (3months ; 6months) & $0.3530(0.2197)$ & 0.1987 \\
\hline (6months; 12 months) & $0.8960(0.6058)$ & 0.1093 \\
\hline \multicolumn{3}{|l|}{ Model (3.7) } \\
\hline (3months; 6months) & $0.3451(0.2128)$ & 0.1987 \\
\hline (6months; 12 months) & $0.8766(0.5931)$ & 0.1084 \\
\hline \multicolumn{3}{|l|}{ GHANA } \\
\hline \multicolumn{3}{|l|}{ Model (3.6) } \\
\hline (3months; 6months) & $-0.3046(0.3108)$ & 0.0769 \\
\hline (6months ; 12 months) & $0.0547(0.2449)$ & 0.0745 \\
\hline \multicolumn{3}{|l|}{ Model (3.7) } \\
\hline (3months ; 6months) & $-0.2812(0.3044)$ & 0.0728 \\
\hline (6months ; 12 months) & $0.0827(0.2696)$ & 0.0751 \\
\hline \multicolumn{3}{|l|}{ KENYA } \\
\hline \multicolumn{3}{|l|}{ Model (3.6) } \\
\hline (3months ; 6months) & $0.0366(0.1699)$ & 0.3846 \\
\hline (6months ; 12 months) & $0.2806(0.2605)$ & 0.0223 \\
\hline \multicolumn{3}{|l|}{ Model (3.7) } \\
\hline (3months; 6months) & $0.0323(0.1528)$ & 0.3743 \\
\hline (6months ; 12 months) & $0.2653(0.2449)$ & 0.0256 \\
\hline \multicolumn{3}{|l|}{ NIGERIA } \\
\hline \multicolumn{3}{|l|}{ Model (3.6) } \\
\hline (3months ; 6months) & $-0.2511(0.0533)^{* *}$ & 0.1602 \\
\hline (6months ; 12 months) & $-0.2100(0.0900)^{* *}$ & 0.1046 \\
\hline \multicolumn{3}{|l|}{ Model (3.7) } \\
\hline (3months; 6months) & $-0.2740(0.0543)^{* *}$ & 0.1593 \\
\hline (6months ; 12 months) & $-0.2376(0.1059)^{* *}$ & 0.0998 \\
\hline \multicolumn{3}{|l|}{ SOUTH AFRICA } \\
\hline \multicolumn{3}{|l|}{ Model (3.6) } \\
\hline (3months; 6months) & $0.0672(0.0583)$ & 0.3414 \\
\hline (6months ; 12 months) & 0.1755 (0.1039)* & 0.3299 \\
\hline \multicolumn{3}{|l|}{ Model (3.7) } \\
\hline (3months; 6months) & $0.0660(0.0560)$ & 0.3397 \\
\hline (6months ; 12 months) & $0.1712(0.1005)^{*}$ & 0.3298 \\
\hline
\end{tabular}

N o t e : Mean (standard deviation) of the regressor coefficient in the second column and determination coefficient in the third column. ${ }^{*}, *$ denote significance at $10 \%$ and $5 \%$ respectively.

S o u r c e : authors' computation from Stata 10/1 outputs. 
In Nigeria and South Africa even though the results are the same irrespective of the model used, they are slightly different with respect to the estimation method used. Indeed, DOLS results are more significant than FMOLS results in Nigeria, while they are different in the matter of significance in the Republic of South Africa.

In Nigeria, the observed difference of the value of the coefficients can be explained by a strong persistence in the spread at the end of the series. The sample size thus plays a role here, since observations are 82 for the FMOLS and 76 for the DOLS. This is because the DOLS add more differenced lags and lead than the FMOLS. Since DOLS is supposed to be more consistent than the FMOLS, we have to conclude that the implicit forward rate have a significant predictive power in Nigeria. But, since the direction of that prediction is not the one expected, one could conclude that operators should not rely on the prediction of the forward rate to have an idea of what would interest rate be in the future. This result suggests that operators on the market in this country are more irrational in their expectations, and that is the conclusion of Hardouvelis (1994) in United-States, even though he used a VAR model of Campbell and Shiller (1991) to confirm it.

In the Republic of South Africa, while the FMOLS and DOLS results are slightly the same in term of coefficient values, they are different in term of significance. The model of 3 months and 6 months rates is significant with FMOLS, while the model of 6 months and 12 months rates is not. The results are the inverse with the DOLS. This could also be explained by strong persistence in the variables. In that context, the sample size would play a role here too. The DOLS being more consistent than the FMOLS, if we consider a threshold of 5\%, we have to conclude that the predictions of the implicit forward rate are irrelevant in the Republic of South Africa. This conclusion is the same for the FMOLS if we consider the determination coefficient. Therefore, operators on that market should not rely on the predictions of the implicit forward rate.

\section{IIICONCLUSION}

The purpose of this study was to verify the predictive power of the implied forward rate of the term structure of interest rates in Africa. Data from Egypt, Ghana, Kenya, Nigeria and the Republic of South Africa were used to this end. A modified version of the yield term premium and the forward term premium 
models of Shiller and McCulloch (1990) were used to test the predictive power of the implicit forward rate, rather than the rational expectations hypothesis. We both used FMOLS and DOLS estimators, since they are more consistent than OLS with non-stationary series.

The results of this study show that the implicit forward rate does not have a significant predictive power in the African countries considered. As a recommendation, economic agents operating in these countries should not rely on the predictions of the implicit forward rate in their decision making. Indeed, it would be difficult to make relevant forecasts of the evolution of economic conditions based on a hypothetical general equilibrium relationship between short-term and long-term rates in these countries, since the markets under consideration are not in a situation of general equilibrium. A direct implication of this observation is the fact that an operator could take advantage of this situation of absence of general equilibrium on these markets to optimise his speculative and arbitrage gains between the short run and the long run. A group of operators applying the same optimisation strategy could thus have a significant influence on the supply of financing for agents in need of financing in the different segments of the market (long term and short term). Furthermore, by extrapolation, the results of this study reveal that a shock occurring in one market segment (such as a change in monetary policy in the short term) would have a marginal effect on the other market segments. In other words, the interest rate formation process would depend exclusively on the conditions of supply and demand for capital in each market segment in these countries.

Concerning interest rate predictability, it would be interesting to study the dynamics of interest rates in each segment before concluding that interest rates in these African markets are unpredictable. In that logic, one could be interested in studying if the VAR predictions of Campbell and Shiller (1991) could be more accurate.

\section{REFERENCES}

Anastasiou, D., Louri, H., \& Tsionas, M.G. (2016). Non-performing loans in the euro area: are core-periphery banking markets fragmented? Bank of Greece working paper, $\mathrm{N}^{\circ} 219,1-48$. http://dx.doi.org/10.2139/ssrn.2868777.

Arize, A.C., Malindretos, J., \& Ghosh, D. (2015). Purchasing power parity-symmetry and proportionality: Evidence from 116 countries. International Review of Economics and Finance, 37, 69-85. http://dx.doi.org/10.1016/j.iref.2014.11.014. 
Bekaert, G., Hodrick, R.J., \& Marshall, D.A. (1997). On Biases In Tests Of Expectation Hypothesis Of The Term Structure Of Interest Rates. Journal Of Financial Economics, 44(3), 309-348. http://dx.doi.org/10.1016/S0304-405X(97)00007-X.

Bidias-Menik, H.P., \& Kamdem, D. (2017). La Structure Par Terme Des Taux D'intétêt: Un test de l'hypothèse des Anticipations sur le marché interbancaire de la Zone UEMOA. Révue Economique et Monétaire [The Term Structure of Interest Rates: A Test of the Expectations Hypothesis on the WAEMU Interbank Market], $\mathrm{N}^{\circ} 21,25-50$.

Boamah, N.A. (2016). Testing the Expectations Hypothesis of the Term Structure of Interest Rate: The Case of Ghana. Journal of African Business, 17(1), 1-15. http://dx.doi. org/10.1080/15228916.2016.1094717.

Bulkley, G., Harris R.D., \& Nawosah, V. (2013). Overconfidence and the Rational Expectations Model of the Term Structure of Interest Rates. XFI Centre for Finance and Investment Working Paper, $\mathrm{N}^{\circ} 11 / 03$. http://dx.doi.org/10.2139/ssrn.2320154.

Bulkley, G., Harris, R.D., \& Nawosah, V. (2015). Can Behavioural Biases Explain the Rejections of the Expectation Hypothesis of the Term Structure of Interest Rates? Journal of Banking and Finance, 58, 179-193. http://dx.doi.org/10.1016/j.jbankfin.2015.03.018.

Campbell, J.Y., \& Shiller, R. (1991). Yield Spreads and Interest Rate Movements: A Bird's Eye View. Review of Economic Studies, 58(3), 495-514. http://dx.doi. org/10.2307/2298008.

Fama, E. (1984). Term Primium in Bond Returns. The Journal of Financial Economics, 13(4), 529-546.

Fama, E., \& Bliss, R.T. (1987). The Information in Long-Maturity Forward rates. The American Economic Review, 77(4), 680-692.

Fisher, I. (1896). Appreciation and Interest. Nashville: American Economic Association.

Froot, K.A. (1987). New Hope For The Expectation Hypothesis of The Term Structure of Interest Rates (Working Paper $N^{\circ} 2363$ ). New York: National Bureau of Economics Researches. http://dx.doi.org/10.3386/w2363.

Gerlach, S. (2003). Interpreting the Term Structure of Interbank Rates in Hong Kong. Pacific-Bassin Financial Journal, 11(5), 593-609. http://dx.doi.org/10.1016/S0927538X(03)00014-3.

Guidolin, M., \& Thornton, D.L. (2008). Prediction of the Short-Term Rates and the Expectation Hypothesis of the Term Structure of Interest Rates. European Central Bank Working Paper, $\mathrm{N}^{\circ} 977$.

Hardouvelis, G.A. (1994). The Term Structure Spread and Future Changes in Long and Short- Rates in the G7 Countries. Journal of Monetary Economics, 33(2), 255-283. http://dx.doi.org/10.1016/0304-3932(94)90003-5.

Hicks, J.R. (1939). Value and Capital (2nd ed.). London: Oxford at the Clarendon Press.

Jondeau, E., \& Ricart, R. (1999). The Expectation Hypothesis of the Term Structure: Test of US, German, French and UK Euro-rates. Journal of International Money and Finance, 18, 725-750. http://dx.doi.org/10.1016/S0261-5606(99)00029-7.

Kao, C., \& Chiang, M.H. (2000). On the Estimation and Inference of a Cointegrated Regression in Panel Data. In B. Baltagi (Ed.). Nonstationary Panels, Panel Cointegra- 
tion, and Dynamic Panels (Advances in Econometrics). Amsterdam: JAI Press. http:// dx.doi.org/10.1016/S0731-9053(00)15007-8.

Longstaff, F.A. (2000). The Term Structure of Very Short-Term Rates: A new Evidence for Expectation Hypothesis. Journal of Financial Economics, 58(3), 397-415. http:// dx.doi.org/10.1016/S0304-405X(00)00077-5.

Lutz, F.A. (1940). The Structure of Interest Rates. Quarterly Journal of Economic, 55(1), 36-63. http://dx.doi.org/10.2307/1881665.

Mankiw, N.G., \& Miron, J.A. (1986). The Changing behaviour of the term structure of Interest Rates. Quaterly Journal of Economics, 101(2), 221-228. http://dx.doi. org/10.2307/1891113.

Masih, A.M.M., \& Masih, R. (1996). Energy Consumption, Real Income and Temporal Causality: Results from a Multi-Country Study Based on Cointegration and ErrorCorrection Modeling Techniques. Energy Economics, 18(4), 315-334. http://dx.doi. org/10.1016/S0140-9883(96)00016-3.

Meiselman, D. (1962). The Term Structure of Interest Rates. Englewood Cliffs (New Jersey): Prentice Hall.

Mishkin, F. (2010). The Economics of Money, Banking and Financial Market. 9th ed. Toronto: Pearson Education Canada.

Modigliani, F., \& Sutch, R. (1966). Innovation in Interest Rates Policy. American Economic Review, 56(1), 178-197.

Montalvo, J.G. (1995). Comparing Cointegrating Regression Estimators: Some Additional Monte Carlo Results. Economics Letters, 48(3-4), 229-234. http://dx.doi. org/10.1016/0165-1765(94)00632-C.

Philips, P.C.B., \& Hansen, B.E. (1990). Statistical Inference in Instrumental Variables Regression with I(1) Processes. Review of Economics Studies, 57(1), 99-125. http:// dx.doi.org/10.2307/2297545.

Roll, R. (1968). The Behavior of Interest Rates: An application of the Efficient Market Model to U.S. Treasury Bill, Ph.D Thesis, Chicago: Graduate School of Business (University of Chicago).

Sargent, T. J. (1972). Rational Expectations and the Term Structure of Interest Rates. Journal of Money, Credit, and Banking, 4(1), 74-97.

Shiller, R.J., \& McCulloch, J.H. (1990). The Term Structure of Interest Rates. In B. Friedman, F. Hahn (Eds). The Handbook of Monetary Economics. Amsterdam: Elsvier. http://dx.doi.org/10.1016/S1573-4498(05)80016-5.

Stock, J., \& Watson, M. (1993). A Simple Estimator of Cointegrating Vector in Higher Order Integrating Systems. Econometrica, 61(4), 783-820. http://dx.doi.org/10. $2307 / 2951763$. 


\section{Webography}

Countries Links toward the central banks data's*

Egypte $\quad$ http://www.cbe.org.eg/en/Pages/default.aspx

Ghana https://www.bog.gov.gh/index.php?option=com_wrapperandvie $\mathrm{w}=$ wrapperandItemid $=231$

Kenya $\quad$ https://www.centralbank.go.ke/

Nigeria http://www.cenbank.org/Functions/export. asp?tablename $=$ securities

RSA https://www.resbank.co.za/Research/Statistics/Pages/ OnlineDownloadFacility.aspx

* Last consultation the 30 June 2017. 